\title{
UJI AKTIVITAS ANTIBAKTERI ISOLAT SENYAWA GOLONGAN TERPENOID DARI BIJI PEPAYA (Carica papaya L.) TERHADAP Staphylococcus aureus SECARA IN VIVO PADA KELINCI JANTAN
}

Antibacterial Activity Test Compounds Group Isolate Terpenoids Seeds of Papaya (Carica papaya L.) on Staphylococcus aureus Rabbit In Vivo On The Male

\author{
Samsuar'), Akhmad Rokiban ${ }^{2)}$, Adityo Hartono ${ }^{2)}$, Ratna Setianingsih ${ }^{3)}$ \\ Jurusan Farmasi, UTB, Bandar Lampung
}

\begin{abstract}
A research on the isolation of terpenoid class of compounds from the seeds of papaya (Carica papaya L.) and test its activity against Staphylococcus aureus in vivo in male rabbits. This research aims to prove that the terpenoid compounds isolated from the seeds of papaya (Carica papaya L.) can inhibit the growth of Staphylococcus aureus in vivo. Separation of terpenoid compounds by column chromatography ((eluent n-hexane: ethyl acetate: ethanol)) resulted in 25 eluates, and then merged based on the results of identification by TLC ( $n$ hexane: ethyl acetate (8: 2)) and the color test reagent Lieburmann -Burchard produce 5 fraction groups. fraction $D$ showed positive terpenoids with $R f 0.75$ and the color purple with Lieburmann-Burchard reagent. study using 15 rabbits were divided into 5 groups: $P 1$ (negative control), P2 (positive control) , P3 (5\% of the test group), P4 (10\% of the test group), P5 (test group 15\%). each group was given the intracutaneous Staphylococcus aureus as $0,2 \mathrm{ml}$ on the backs of rabbits. Having symptoms of infection each group was given the test substance 3 times a day topically, the observed parameter is the diameter of the wound, and histopathological observations performed on days 3,6 and 9 Analysis of the results of research conducted using ANSIRA showed highly significant differences between groups ( $p<0.05)$. Then proceed with the analysis of the results of the analysis HSD test showed highly significant differences in the test group $5 \%$ to $10 \%$ of the test group and the test group $15 \%$. Isolates terpenoid class of compounds from the seeds of papaya (Carica Papaya L.) with a concentration of $10 \%$ and $15 \%$ can inhibit the growth of Staphylococcus aureus.
\end{abstract}

Keywords: Antibacterial, Staphylococcus aureus, male rabbits

\section{ABSTRAK}

Telah dilakukan penelitian tentang isolasi senyawa golongan terpenoid dari biji pepaya (Carica papaya L.) dan uji aktivitasnya terhadap Staphylococcus aureus secara in vivo pada kelinci jantan. Penelitian ini bertujuan untuk membuktikan bahwa senyawa terpenoid hasil isolasi dari biji pepaya (Carica papaya L.) dapat menghambat pertumbuhan bakteri Staphylococcus aureus secara in vivo. Pemisahan senyawa terpenoid dengan kromatografi kolom ((eluen n-heksan : etil asetat : etanol)) menghasilkan 25 eluat, kemudian digabungkan berdasarkan hasil identifikasi dengan KLT ((n-heksan : etil asetat (8:2)) dan uji warna dengan pereaksi Lieburmann-Burchard menghasilkan 5 kelompok fraksi. Fraksi D menunjukkan positif terpenoid dengan harga Rf 0,75 dan warna ungu dengan 


\section{JFL \\ Jurnal Farmasi Lampung ～Vol.10. No.1 Juni 2021}

pereaksi Lieburmann-Burchard. Penelitian ini menggunakan 15 ekor kelinci yang dibagi dalam 5 kelompok yaitu P1(kontrol negatif), P2 (kontrol positif), P3 (kelompok uji 5\%), P4 (kelompok uji 10\%), P5(kelompok uji 15\%). Setiap kelompok diberi bakteri Staphylococcus aureus secara intrakutan sebanyak $0,2 \mathrm{ml}$ pada punggung kelinci. Setelah timbul gejala infeksi setiap kelompok diberi zat uji sebanyak 3 kali sehari dengan cara dioleskan, parameter yang diamati adalah diameter luka, dan dilakukan pengamatan histopatologi pada hari ke-3,6 dan 9. Analisis hasil penelitian dilakukan menggunakan ANSIRA menunjukkan perbedaan sangat signifikan antar kelompok $(p<0,05)$. Kemudian analisis dilanjutkan dengan uji BNJ hasil analisis menunjukkan perbedaan sangat signifikan pada kelompok uji 5\% dengan kelompok uji 10\% dan kelompok uji $15 \%$. Isolat senyawa golongan terpenoid dari biji pepaya (Carica Papaya L.) dengan konsentrasi $10 \%$ dan $15 \%$ dapat menghambat pertumbuhan Staphylococcus aureus.

Kata kunci: Antibakteri, Staphylococcus aureus, kelinci jantan

\section{PENDAHULUAN}

Infeksi merupakan masalah yang paling banyak dijumpai pada kehidupan sehari hari. Staphylococcus aureus adalah bakteri gram positifyang merupakan anggota flora normal kulit dan selaput lendir manusia, serta patogen utama pada manusia dan hewan (Jawetz et al, 1996). Bakteri ini menginfeksi ke dalam kulit melalui folikel rambut, muara kelenjar keringat, luka besar dan kecil, dan cepat menjadi resisten terhadap banyak zat antimikroba sehingga sering menimbulkan masalah dalam pengobatannya (Jawetz et al, 1986).

Zat antibakteri dapat berasal dari bahan kimia sintesis maupun alami. Senyawa antibakteri alami dapat berasal dari tanaman yaitu bunga, buah, biji, rimpang, umbi, batang dan daun. Salah satu tanaman yang dapat dimanfaatkan sebagai antibakteri adalah tanaman pepaya (Carica papaya L.). Biji pepaya dapat dimanfaatkan sebagai obat diare, obat penyakit kulit, bahan baku obat masuk angin dan sebagai sumber untuk mendapatkan minyak dengan kandungan asam-asam lemak tertentu (Warisno, 2003).

Hasil uji fitokimia terhadap ekstrak kental n-heksan biji pepaya diketahui mengandung senyawa metabolit sekunder golongan terpenoid, flavanoid, alkaloid, dan saponin. Secara kualitatif berdasarkan terbentuknya endapan atau intensitas warna yang dihasilkan dengan pereaksi uji fitokimia, diketahui bahwa kandungan senyawa metabolit sekunder golongan terpenoid merupakan komponen utama biji pepaya (Sukadana dkk, 2008).

Berdasarkan penelitian yang dilakukan oleh Sukadana dkk (2008) senyawa golongan terpenoid dari biji pepaya dengan konsentrasi 1000 ppm memiliki potensi menghambat pertumbuhan bakteri Staphylococcus aures dengan diameter hambat sebesar $7 \mathrm{~mm}$, maka perlu dilakukan penelitian tentang aktivitas antibakteri senyawa golongan terpenoid dari biji pepaya (Carica papaya L.) terhadap Staphylococcus aureus secara in vivo dan pemeriksaan histopatologi jaringan yang terinfeksi. 


\section{METODOLOGI}

\section{Alat dan Bahan}

Alat yang digunakan adalah berbagai alat gelas, rotary vacuum evaporator, seperangkat alat kromatografi (KLT dan kolom), spektrofotometer UV, pencukur bulu, gunting, kasa steril, plester, spuit $1 \mathrm{ml}$, pisau bedah, tissue processor, mikrotom, penangas air, gelas objek, gelas penutup, dan mikroskop electron.

Bahan yang digunakan dalam penelitian ini adalah biji pepaya (Carica papaya L), biakan bakteri Staphylococcus aureus, n-heksan, asam asetat anhidrat, $\mathrm{H}_{2} \mathrm{SO}_{4}$, silica gel GF 254, silika gel 60, etilasetat, etanol, aquades, etanol $96 \%$, eter, larutan BNF (Netral Buffer Formalin) $10 \%$, salep gentamicin $0,1 \%$, larutan Xylol, alkohol, dan parafin.

\section{Prosedur Penelitian}

\section{Pengumpulan dan penyiapan bahan}

Bahan yang digunakan berupa biji pepaya yang diperoleh dari Desa Negeri Sakti Kabupaten Pesawaran Lampung. Biji pepaya yang digunakan adalah biji pepaya yang berwarna putih yaitu biji berasal dari pepaya muda yang berumur 2,5-3 bulan. Biji pepaya dipisahkan dari bagian-bagian buah lain, dicuci dan dibersihkan dari bahan-bahan asing dan pengotor lainnya, kemudian direndam dalam etanol panas agar lapisan air dan lapisan lemak dapat tertarik. Setelah itu ditiriskan dan dikeringkan dengan oven pada suhu $40^{\circ} \mathrm{C}$ kemudian digiling dan diayak.

\section{Pembuatan zat uji}

$100 \mathrm{~g}$ serbuk kering biji pepaya yang diperoleh dimaserasi dalam botol gelap menggunakan pelarut $n$ heksan sebanyak $400 \mathrm{ml}$ sambil diaduk. Ekstrak yang didapat diuapkan dengan rotary vacuum evaporator sehingga diperoleh ekstrak kental $n$-heksan. Ekstrak kental tersebut diuji fitokimia dengan pereaksi Liebermann-Burchard untuk menentukan ada tidaknya terpenoid. Ekstrak yang positif mengandung terpenoid akan menghasilkan cincin warna merah atau ungu.

\section{Pemilihan eluen}

Pemilihan eluen dilakukan dengan metode KLT menggunakan plat silika gel GF $254 \mathrm{~nm}$ sebagai fase diam dan beberapa variasi eluen seperti n-heksan $100 \%$, etil asetat $100 \%$, etanol $100 \%$, n-heksan : etil asetat (1:9), $\mathrm{n}$-heksan : etil asetat (2:8), n-heksan : etil asetat (3:7), nheksan : etil asetat (4:6), n-heksan : etil asetat (5:5), n-heksan : etil asetat (6:4), n-heksan : etil asetat (7:3), nheksan : etil asetat (8:2), n-heksan : etil asetat (9:1), sebagai fase gerak untuk mengetahui variasi eluen yang paling sesuai. Hasil elusi pada pelat disemprot larutan LiebermannBurchard dan diamati di bawah lampu UV untuk melihat bercakbercak pemisahan yang dihasilkan.

\section{Pemisahan dengan kromatografi kolom}

Ekstrak kental positif terpenoid dipisahkan dengan kromatografi kolom (n-heksan : etil asetat: etanol). Masing-masing eluat hasil kromatografi kolom dianalisis dengan mengunakan KLT. Hasil KLT dengan nilai $\mathrm{Rf}$ yang sama dikelompokkan dalam satu kelompok fraksi. Masing-masing kelompok fraksi diuji untuk terpenoid menggunakan pereaksi LieburmannBurchard. Fraksi yang positif 


\begin{abstract}
JFL
Jurnal Farmasi Lampung

mengandung terpenoid adalah fraksi yang menghasilkan cincin warna merah atau ungu. Fraksi yang positif mengandung terpenoid kemudian dilanjutkan dengan uji kemurnian secara KLT dengan menggunakan $\mathrm{n}$-heksan : etil asetat (8:2) sebagai fase gerak. Setelah proses elusidasi selesai hasil elusi pada pelat disemprot dengan larutan Liebermann-Burchard dan diamati di bawah lampu UV. Fraksi yang menghasilkan satu noda dapat dikatakan sebagai isolat relatif murni secara KLT, Kemudian hitung nilai Rf nya
\end{abstract}

\section{Sterilisasi alat dan bahan}

Alat-alat yang digunakan seperti tabung reaksi, erlenmeyer, gelas ukur, batang pengaduk, cawan petri, pipet tetes, ditutup dengan alumunium foil kemudian disterilkan dengan autoklaf pada suhu $121^{\circ} \mathrm{C}$ dan tekanan $1 \mathrm{~atm}$ selama 15 menit. Untuk pinset dan ose disterilkan dengan pemijaran (Lay, 1994). Bahan yang digunakan seperti aquades, media NA, media NB dan $\mathrm{Nacl}$ disterilkan dengan menggunakan autoklaf pada suhu $121^{\circ} \mathrm{C}$ dan tekanan $1 \mathrm{~atm}$ selama 15 menit (Lay, 1994). Bahan yang tidak tahan terhadap pemanasan dibuat dan dikerjakan secara aseptis dalam laminar air flow. Sedangkan esktrak biji pepaya disterilkan dengan menggunakan penyaring bakteri.

\section{Penyiapan suspensi bakteri Staphylococcus aureus}

\section{Pembuatan media NA}

Sebanyak 28 gram Nutrient Agar dilarutkan ke dalam 1 liter aquades dan dipanaskan hingga mendidih kurang lebih 10-15 menit lalu disterilkan dengan menggunakan autoklaf dengan suhu $121^{\circ} \mathrm{C}$ tekanan 1atm selama 15 menit (lay, 1994).

\section{Pembuatan Standar Kekeruhan Larutan ( Larutan Mc. Farland).}

Larutan $\mathrm{H}_{2} \mathrm{SO}_{4} \quad 0,36 \mathrm{~N}$ sebanyak $99,5 \mathrm{ml}$ dicampurkan dengan larutan $\mathrm{BaCl}_{2} \cdot 2 \mathrm{H}_{2} \mathrm{O} 1,175 \%$ sebanyak $0,5 \mathrm{ml}$ dalam Erlenmeyer. Kemudian dikocok sampai terbentuk larutan yang keruh. Kekeruhan ini dipakai sebagai standar kekeruhan suspensi bakteri uji (Victor dalam Tandy dkk, 2012).

\section{Penyiapan Biakan Bakteri Staphylococcus aureus}

Biakan bakteri Staphylococcus aureus diperoleh dari Laboratorium Bakteriologi Balai Penyelidikan dan Pengujian Veteriner (BPPV).

\section{Pembuatan suspensi Bakteri Staphylococcus aureus}

Biakan bakteri Staphylococcus aureus hasil peremajaan dari media NA diambil sebanyak satu mata ose lalu dimasukkan ke dalam tabung reaksi yang berisi $2 \mathrm{ml}$ larutan $\mathrm{NaCL} 0,9 \%$ dan Kekeruhannya disetarakan dengan larutan Mc. Farland yang setara dengan 758 juta bakteri per $\mathrm{ml}$.

\section{Perlakuan Pada Kelinci}

Penelitian ini menggunakan 15 ekor kelinci. Kelinci dibagi menjadi 5 kelompok yaitu kelompok kontrol negatif (P1), kontrol positif (P2), dan kelompok uji 5\% (P3), kelompok uji $10 \%$ (P4), kelompok uji 15\% (P5) masing-masing kelompok terdiri dari 3 ekor. Kelinci diadaptasikan terlebih dahulu didalam kandang selama 1 minggu sebelum dilakukan penelitian. Setiap punggung kelinci diberi tanda berupa lingkaran dengan diameter $\pm 5 \mathrm{~cm}$ sebanyak 4 


\section{JFL \\ Jurnal Farmasi Lampung ～Vol.10. No.1 Juni 2021}

daerah dengan menggunakan spidol kemudian bulu pada punggung kelinci yang telah diberi tanda dicukur dan kelinci diistirahatkan selama 24 jam. Daerah pada punggung kelinci yang telah dicukur disuntikkan suspensi Staphylococcus aureus secara intrakutan sebanyak $0,2 \mathrm{ml}$ lalu ditutup dengan kasa steril dan diistirahatkan kembali (Tandy, dkk, 2012).

Setelah timbul gejala-gejala infeksi pada kelinci yang ditandai dengan panas, merah, dan bengkak, masing-masing daerah infeksi pada kelompok P3,P4,P5 diberi bahan uji sebanyak $0.5 \mathrm{ml}$ dengan cara dioleskan, pada kelompok $\mathrm{P} 1$ hanya diberi larutan CMC $1 \%$ dan pada kelompok P2 diberi salep gentamicin $0,1 \%$ kemudian ditutup dengan kasa steril. Pemberian zat uji dan salep gentamicin dilakukan sebanyak 3 kali sehari (pagi, siang, sore).

\section{Pengambilan Sampel Kulit}

Sampel kulit diambil pada hari ke- 3 , 6,9 pasca terjadinya infeksi. Daerah punggung yang diambil kulitnya dibersihkan dari rambut yang mulai tumbuh. Kelinci dieuthanasia dengan menggunakan kloroform terlebih dahulu. Kemudian kulit pada daerah luka dipotong dengan ukuran $\pm 1,5 \mathrm{~cm}$ dengan menggunakan skapel yang telah disterilkan terlebih dahulu. Kulit yang sudah dipotong difiksasi dengan larutan BNF (Buffer Neutral Formaline) $10 \%$ selama \pm 48 jam.

\section{Fiksasi sediaan kulit dan pembuatan preparat histopatologi (Muntiha, 2001)}

Potongan sediaan kulit dimasukkan ke dalam kaset tissue, kemudian didehidrasi dengan cara merendam sediaan secara berturut-turut ke dalam alkohol $70 \%, 80 \%, \quad 90 \%$, alkohol absolut I, alkohol absolut II selama 2 jam. Kemudian dilakukan pembeningan dengan cara merendam ke dalam larutan xylol I, xylol II selama 2 jam. Lalu dilakukan parafinasi dengan cara mencelupkan sediaan ke dalam parafin I, dan terakhir ke dalam parafin II selama 2 jam.

Jaringan kemudian dimasukkan ke dalam alat pencetak berisi parafin cair. Letak jaringan diatur sedemikian rupa agar tetap berada di tengah blok parafin. Setelah mulai membeku, parafin ditambah kembali hingga alat pencetak penuh dan dibiarkan hingga parafin mengeras. Kemudian sediaan dipotong menggunakan mikrotom dengan ketebalan 5 mikron.

Hasil pemotongan yang berbentuk pita diletakkan di atas permukaan air hangat $45^{\circ} \mathrm{C}$ dengan tujuan menghilangkan lipatan-lipatan pada pita akibat pemotongan. Setelah itu sediaan diangkat dari permukaan air dengan gelas objek yang telah diulasi larutan albumin yang berguna untuk merekatkan sediaan. Kemudian preparat dikeringkan semalam dalam inkubator bersuhu $60^{\circ} \mathrm{C}, \quad$ Selanjutnya dilakukan pewarnaan umum Haematoxylin Eosin.

\section{Pembuatan sediaan Haematoxilin $\operatorname{Eosin}$ (HE)}

Sediaan histopatologi yang telah didapatkan dimasukkan ke dalam xylol dua kali selama dua menit. Kemudian sediaan direhidrasi yang dimulai dari alkohol absolut sampai alkohol $80 \%$ dengan waktu masingmasing 2 menit. Selanjutnya sediaan dicuci dalam air mengalir dan dikeringkan. 


\section{JFL \\ Jurnal Farmasi Lampung ～Vol.10. No.1 Juni 2021}

Setelah sediaan kering kemudian diberi pewarna mayer's hemaktosilin selama 8 menit, kemudian dibilas dengan air mengalir dan dicuci dengan lithium karbonat selama 1530 detik, dibilas dengan air, dan akhirnya diwarnai dengan pewarna eosin selama 2 menit. Pewarna eosin yang berlebihan dihilangkan dengan cara mencuci sediaan pada air yang mengalir, setelah itu sediaan dikeringkan.

Kemudiaan sediaan dicelupkan ke dalan alkohol $90 \%$ sebanyak 10 kali celupan, alkohol absolut I 10 kali celupan, alkohol absolut II selama 2 menit, xylol I selama I menit, dan xylol II selama 2 menit. Sediaan lalu dikeringkan terlebih dahulu sebelum ditetesi dengan perekat permount dan kemudian ditutup dengan gelas penutup dan disimpan beberapa menit hingga zat perekatnya mengering. Preparat siap untuk diamati dibawah mikroskop cahaya. Parameter yang diamati adalah area nekrosis, area abses, sel radang, granuloma, jaringan granulasi.

\section{HASIL DAN PEMBAHASAN}

Hasil ekstraksi serbuk biji pepaya sebanyak 100 gram dengan diperoleh ekstrak kental sebanyak 12,5 gram. Identifikasi dengan uji warna dilakukan pada maserat sebelum fraksinasi dengan menggunakan pereaksi LieburmannBurchard menghasilkan cincin warna ungu, hal ini menunjukkan bahwa di dalam biji pepaya positif mengandung senyawa terpenoid.

\section{Hasil Fraksinasi dengan kromatografi kolom}

Hasil fraksinasi dengan kromatografi kolom menggunakan fase gerak nheksan:etil menghasilkan kemudian digabungkan berdasarkan hasil identifikasi dengan KLT menggunakan fase gerak $n$ heksan:etil asetat (8:2) dan fase diam silica gel GF 254 menghasilkan 5 kelompok fraksi, kemudian pada masing-masing kelompok fraksi dilakukan uji warna dengan pereaksi Lieburmann-Burchard dan menghasilkan berbagai warna yang terangkum dalam tabel berikut ini.

Tabel 4.1 Hasil fraksinasi ekstrak biji papaya

\begin{tabular}{|l|l|l|l|l|}
\hline No & Eluat & fra & Harga & Warna \\
\hline 1 & $1-5$ & A & 0,59 & Kuning \\
\hline 2 & $6-10$ & B & 0,78 & Hijau \\
\hline 3 & $11-14$ & C & 0,67 & $\begin{array}{l}\text { Merah } \\
\text { kecoklatan }\end{array}$ \\
\hline 4 & $15-21$ & D & 0,75 & Ungu \\
\hline 5 & $22-25$ & E & 0,82 & Kuning \\
\hline
\end{tabular}

dari data pada tabel menunjukkan fraksi yang positif terpenoid adalah fraksi $D$ dengan harga $\operatorname{Rf} 0,75$ dan menghasilkan warna ungu setelah ditambah dengan pereaksi Lieburmann-Burchard.

Fraksi ini dipilih untuk analisis KLT selanjutnya dengan menggunakan berbagai eluen dan menghasilkan satu noda berwarna ungu setelah disemprot dengan pereaksi semprot Libermann-Burchard dan dipanaskan pada suhu $85-90^{\circ} \mathrm{C}$ maka fraksi $D$ dapat dianggap sebagai isolat relatif murni secara KLT (Harbone, 1987). 


\section{JFL \\ Jurnal Farmasi Lampung ～Vol.10. No.1 Juni 2021}

Hasil KLT fraksi $D$ dengan eluen $n-$ heksan : etil asetat (8:2) dengan eluen toluene : kloroform (7:3) terlihat pada gambar 4.1

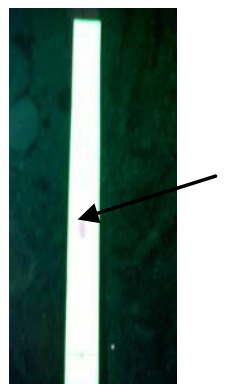

a

Gambar 4.1 Hasil KLT fraksi D dengan eluen berbeda (tanda panah menunjukkan senyawa terpenoid ) a. toluene : kloroform (7:3) b.n-heksan : etil asetat (8:2)

\section{Hasil Data Pemeriksaan Histopatologi}

Hasilpengamatan histopatologi dapat dilihat pada tabel 4.3, 4.4, 4.5, yakni sel radang, area nekrosis, area abses, granuloma, dan jaringan granulasi. Pada hari ke-3 masingmasing kelompok terdapat sel radang, nekrosis, abses, dan granuloma yang masih banyak dengan sebutan difus, pada hari ke-
6 kelompok kontrol negatif dan kelompok uji $5 \%$ tidak mengalami perubahan masih tetap sama dengan hari ke-3, sedangkan pada kelompok uji $10 \%$, dan kelompok uji $15 \%$ area abses, area nekrosis, dan granuloma sudah berkurang dengan sebutan multifukal (sedang) dan sudah mulai terlihat jaringan granulasi sedikit dengan sebutan fukal.

Pada hari ke-9 kelompok kontrol negatif sama sekali tidak mengalami perubahan sel radang, area abses, area nekrosis, granuloma terdapat masih banyak dan tidak terjadinya jaringan granulasi, hal ini disebabkan karena tidak dilakukan pengobatan, walaupun diberi larutan CMC 1\% tidak mempengaruhi proses penyembuhan, pada kelompok uji $5 \%$ sel radang, area abses, granuloma, dan jaringan granulasi menjadi sedikit (fukal), sedangkan pada kelompok kontrol positif, kelompok uji 10\%, dan kelompok uji $15 \%$ sel radang, area abses, sudah tidak ada lagi tetapi nekrosis dan granuloma masih sedikit (fukal), dan jaringan granulasi bertambah (multifukal).

Tabel 4.2 Data pemeriksaan histopatologi pada kelinci hari ke-3

\begin{tabular}{|l|l|l|l|l|l|}
\hline \multirow{2}{*}{ Pengamatan } & \multicolumn{5}{l}{ Hari ke-3 } \\
\cline { 2 - 6 } & $\begin{array}{l}\text { Kontrol } \\
(-)\end{array}$ & $\begin{array}{l}\text { Kontrol } \\
(+)\end{array}$ & $\begin{array}{l}\text { Kelompok } \\
\text { uji 5\% }\end{array}$ & $\begin{array}{l}\text { Kelompok } \\
\text { uji 10\% }\end{array}$ & $\begin{array}{l}\text { Kelompo } \\
\text { k uji 15\% }\end{array}$ \\
\hline Sel radang & +++ & +++ & +++ & +++ & +++ \\
\hline Area nekrosis & +++ & +++ & +++ & +++ & +++ \\
\hline Area abses & +++ & +++ & +++ & +++ & +++ \\
\hline Granuloma & +++ & +++ & +++ & +++ & +++ \\
\hline $\begin{array}{l}\text { Jaringan } \\
\text { granulasi }\end{array}$ & - & - & - & - & - \\
\hline
\end{tabular}

Keterangan :

Tanda $(+++)=$ difus (banyak)

Tanda $(++) \quad=$ multifukal (sedang)

Tanda $(+) \quad=$ fukal (sedikit) 


\section{JFL \\ Jurnal Farmasi Lampung ～Vol.10. No.1 Juni 2021}

Tabel 4.3 Data pemeriksaan histopatologi pada kelinci hari ke-6

\begin{tabular}{|l|l|l|l|l|l|}
\hline \multirow{2}{*}{ Pengamatan } & \multicolumn{5}{|c|}{ Hari ke-6 } \\
\cline { 2 - 6 } & $\begin{array}{l}\text { Kontrol } \\
(-)\end{array}$ & $\begin{array}{l}\text { Kontrol } \\
(+)\end{array}$ & $\begin{array}{l}\text { Kelompok } \\
\text { uji } 5 \%\end{array}$ & $\begin{array}{l}\text { Kelompok } \\
\text { uji 10\% }\end{array}$ & $\begin{array}{l}\text { Kelompok } \\
\text { uji 15\% }\end{array}$ \\
\hline Sel radang & +++ & ++ & +++ & +++ & ++ \\
\hline $\begin{array}{l}\text { Area } \\
\text { nekrosis }\end{array}$ & +++ & ++ & +++ & ++ & ++ \\
\hline Area abses & +++ & ++ & +++ & ++ & ++ \\
\hline Granuloma & +++ & ++ & ++ & ++ & ++ \\
\hline $\begin{array}{l}\text { Jaringan } \\
\text { granulasi }\end{array}$ & - & + & - & + & + \\
\hline
\end{tabular}

Keterangan :

Tanda $(+++)=$ difus (banyak)

Tanda $(++) \quad=$ multifukal (sedang)

Tanda $(+) \quad=$ fukal (sedikit)

Tabel 4.4 Data pemeriksaan histopatologi pada kelinci hari ke-9

\begin{tabular}{|l|l|l|l|l|l|}
\hline Pengamatan & \multicolumn{5}{|l|}{ Hari ke-9 } \\
\cline { 2 - 7 } & $\begin{array}{l}\text { Kontrol } \\
(-)\end{array}$ & $\begin{array}{l}\text { Kontrol } \\
(+)\end{array}$ & $\begin{array}{l}\text { Kelompok } \\
\text { uji 5\% }\end{array}$ & $\begin{array}{l}\text { Kelompok } \\
\text { uji 10\% }\end{array}$ & $\begin{array}{l}\text { Kelompok } \\
\text { uji 15\% }\end{array}$ \\
\hline Sel radang & ++ & - & + & - & - \\
\hline Area nekrosis & ++ & - & + & - & - \\
\hline Area abses & ++ & - & - & - & - \\
\hline Granuloma & ++ & - & + & + & - \\
\hline $\begin{array}{l}\text { Jaringan } \\
\text { granulasi }\end{array}$ & - & ++ & ++ & ++ & ++ \\
\hline
\end{tabular}

Keterangan :

Tanda $(+++)=$ difus (banyak)

Tanda $(++) \quad=$ multifukal (sedang)

Tanda $(+) \quad=$ fukal (sedikit)

\section{Hasil Analisis Data}

Hasil uji Analisis Sidik Ragam (ANSIRA) pengukuran diameter luka pada kelinci jantan hari ke-3 dapat dilihat pada tabel 4.7

Tabel 4.7 Hasil analisis sidik ragam

\begin{tabular}{|l|l|l|l|l|l|l|}
\hline S.K & DB & JK & KT & F. Hitung & F Tabel \\
\cline { 5 - 7 } & & & & & 0,05 & 0,01 \\
\hline Perlakuan & 4 & 0,014 & 0,0035 & $26,923^{* *}$ & 3,0566 & 4,3932 \\
\hline Galat & 15 & 0,002 & 0,00013 & & \\
\hline Total & 19 & \multicolumn{5}{l}{} \\
Keterangan : ${ }^{* *}$ sangat signifikan
\end{tabular}




\section{Jurnal Farmasi Lampung Vol.10. No.1 Juni 2021}

Setelah dilakukan analisis sidik ragam didapat KK 1,975\% sehingga dapat dilanjutkan ke uji BNJ. Hasil uji BNJ dapat dilihat pada tabel 4.8

Tabel 4.8 Hasil uji beda nyata jujur (BNJ) pada hari ke-3

\begin{tabular}{|l|l|l|l|l|l|}
\hline Perlakuan & Rerata & 1 & 2 & 3 & 4 \\
\hline P1 & 1,375 & - & & & \\
\hline P2 & 1,312 & $0,063^{* *}$ & & & \\
\hline P3 & 1,358 & $0,017^{\text {tn }}$ & $0,046^{* *}$ & & \\
\hline P4 & 1,310 & $0,065^{* *}$ & $0,002^{\text {tn }}$ & $0,048^{* *}$ & \\
\hline P5 & 1,315 & $0,060^{* *}$ & $0,003^{\text {tn }}$ & $0,043^{* *}$ & $0,005^{\text {tn }}$ \\
\hline
\end{tabular}

Keterangan :

* $\quad=$ signifikan

** $\quad=$ sangat signifikan

tn $=$ tidak signifikan

Hasil uji analisis sidik ragam pengukuran diameter luka pada kelinci jantan hari ke-6 dapat dilihat pada tabel 4.10

Tabel 4.10 Hasil analisis sidik ragam

\begin{tabular}{|c|c|c|c|c|c|c|}
\hline \multirow[t]{2}{*}{ S.K } & \multirow[t]{2}{*}{ DB } & \multirow[t]{2}{*}{ JK } & \multirow[t]{2}{*}{ KT } & F. Hitung & \multicolumn{2}{|l|}{ F Tabel } \\
\hline & & & & & 0,05 & 0,01 \\
\hline Perlakuan & 4 & 0,846 & 0,2115 & 10,575 ** & 3,0566 & 4,3932 \\
\hline Galat & 15 & 0,003 & 0,0002 & & & \\
\hline Total & 19 & & & & & \\
\hline
\end{tabular}

Keterangan : ${ }^{* *}=$ sangat signifikan

Setelah dilakukan analisis sidik ragam didapat $\mathrm{KK} 3,138 \%$ sehingga dapat dilanjutkan ke uji BNJ. Hasil uji BNJ dapat dilihat pada tabel 4.11

Tabel 4.11 Hasil uji beda nyata jujur (BNJ) pada hari ke-6

\begin{tabular}{|l|l|l|l|l|l|}
\hline Perlakuan & Rerata & 1 & 2 & 3 & 4 \\
\hline P1 & 1,065 & & & & \\
\hline P2 & 0,617 & $0,448^{* *}$ & & & \\
\hline P3 & 1,062 & $0,003^{\text {tn }}$ & $0,445^{* *}$ & & \\
\hline P4 & 0,660 & $0,405^{\star *}$ & $0,043^{* *}$ & $0,402^{* *}$ & \\
\hline P5 & 0,657 & $0,408^{* *}$ & $0,040^{* *}$ & $0,405^{* *}$ & $0,003^{\text {tn }}$ \\
\hline
\end{tabular}

Keterangan :

* $\quad=$ signifikan

** $\quad=$ sangat signifikan

tn $\quad=$ tidak signifikan

Hasil uji analisis sidik ragam pengukuran diameter luka pada kelinci jantan hari ke-9 dapat dilihat pada tabel 4.14 


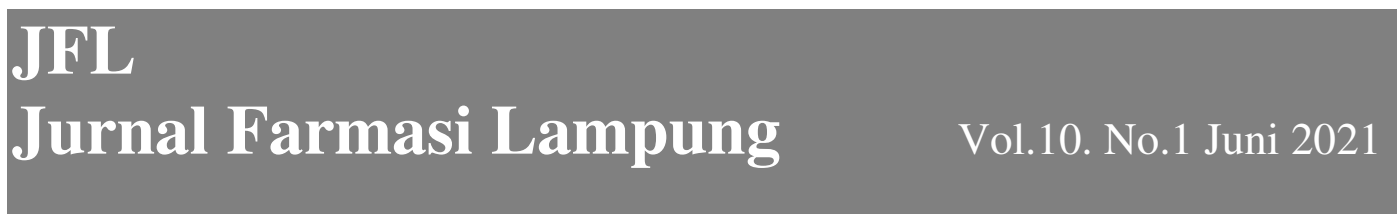

Tabel 4.14 Hasil analisis sidik ragam

\begin{tabular}{|l|l|l|l|l|l|l|}
\hline S.K & DB & JK & KT & F. Hitung & F Tabel \\
\cline { 5 - 7 } & & & & & 0,05 & 0,01 \\
\hline Perlakuan & 4 & 0,129 & 0,03225 & $48,134^{* *}$ & 3,0566 & 4,3932 \\
\hline Galat & 15 & 0,001 & 0,000067 & & \\
\hline Total & 19 & \multicolumn{5}{l}{} \\
Keterangan : ${ }^{* *}$ sangat signifikan
\end{tabular}

Setelah dilakukan analisis sidik ragam didapat $\mathrm{KK} 3,828 \%$ sehingga dapat dilanjutkan ke uji BNJ. Hasil uji BNJ dapat dilihat pada tabel 4.15

Tabel 4.15 Hasil uji Beda Nyata Jujur (BNJ)

\begin{tabular}{|l|l|l|l|l|l|}
\hline Perlakuan & Rerata & P1 & P2 & P3 & P4 \\
\hline P1 & 0,282 & & & & \\
\hline P2 & 0,122 & $0,160^{* *}$ & & & \\
\hline P3 & 0,280 & $0,002^{\text {tn }}$ & $0,158^{* *}$ & & \\
\hline P4 & 0,120 & $0,162^{* *}$ & $0,002^{\text {tn }}$ & $0,160^{\star *}$ & \\
\hline P5 & 0,110 & $0,172^{* *}$ & $0,012^{\text {tn }}$ & $0,170^{* *}$ & $0,010^{\text {tn }}$ \\
\hline
\end{tabular}

Keterangan :

$$
\begin{array}{ll}
* & =\text { signifikan } \\
* * & =\text { sangat signifikan } \\
\text { tn } & =\text { tidak signifikan }
\end{array}
$$

Dari hasil analisis data dengan BNJ yang diperoleh pada hari ke-3, 6 , dan 9 dapat dilihat bahwa senyawa terpenoid dari biji pepaya berpengaruh sangat signifikan dalam memacu kesembuhan luka infeksi oleh Staphylococcus aureus pada kulit kelinci jantan.

\section{KESIMPULAN DAN SARAN}

\section{Kesimpulan}

Berdasarkan hasil penelitian yang telah dilakukan terhadap efek antibakteri senyawa terpenoid biji pepaya pada kelinci jantan yang terinfeksi bakteri Staphylococcus aureus dapat disimpulkan bahwa senyawa terpenoid hasil isolasi dari biji papaya dengan konsentrasi $10 \%$ dan $15 \%$ dapat menghambat pertumbuhan bakteri Staphylococcus aureus secara in vivo.

\section{Saran}

Berdasarkan manfaat, dan efek yang ditimbulkan maka disarankan kepada peneliti selanjutnya untuk melakukan analisis efek terpenoid terhadap bakteri jenis lain.

\section{DAFTAR PUSTAKA}

(1) Harborne. J. B. 1987. Metode Fitokimia edisi ke-2. Bandung: Institut Teknologi Bandung.

(2) Jawetz E, et al. 1986. "Mikrobiologi Untuk Profesi Kesehatan", diterjemahkan oleh 
Bonang G., Edisi XVI, Jakarta: EGC Kedokteran.

(3) Jawetz E, et al. 1996. "Mikrobiologi Kedokteran". Ed ke-20. Nugroho E, Maulany RF, penerjemah. Jakarta: EGC. Terjemahan dari: Medical Microbiology.

(4) Lay, B, W.,"Analisa Mikroba di Laboratorium", PT. Raja Grafindo Persada, Jakarta.

(5) Muntiha, Mohammad. 2001. "Teknik pembuatan Preparat Histopatologi dari Jaringan Hewan dengan Pewarnaan Hematoksilin Eosin". Balai Penelitian Veteriner Bogor. Bogor.

(6) Sukadana, IM dkk. 2008. "Aktivitas antibakteri senyawa golongan terpenoid Dari biji pepaya (carica papaya l)". Jurnal kimia. Universitas Udayana. Bali.

(7) Tandy, Deborah, dkk. 2012. "Efek Antibakteri Salep Ekstrak Rimpang lengkuas putih (alpinia galangal L) pada kulit punggung kelinci yang dibuat infeksi staphs aureus.

STIKES Muhammadiyah Manado. Manado.

(8) Warisno. 2003. "Budi Daya Pepaya". Kanisius. Yogyakarta 